\title{
TINOSPORA EXTRACT (TINOSPORA CRISPA (L.) MIERS.) ENCAPSULATION WITH SODIUM ALGINATE ISOLATED FROM BROWN ALGAE (SARGASSUM ILICIFOLIUM)
}

\author{
SAMRAN ${ }^{1 *}$, TANJUNG HR ${ }^{2}$ \\ ${ }^{1}$ Department of Pharmacy, Faculty of Mathematics and Natural Science, University of Muslim Nusantara Al-Washliyah, Jl. Gaharu II No. 2 , \\ Medan Amplas, Medan 20147, Indonesia. ${ }^{2}$ Department of Pharmacology, Faculty of Pharmacy, Universitas Sumatera Utara, Jl. Tridharma \\ No. 5 Kampus USU, Medan, Indonesia. Email: samranamatrejo@gmail.com
}

Received: 08 December 2017, Revised and Accepted: 28 July 2017

ABSTRACT

Objective: Brotowali (Tinospora crispa) is well known as a bitter medicinal plant and traditionally has been used to treat rheumatism, gout, bruise, and fever and also to stimulate appetite. The bitter flavor of Tinospora extract has influenced the patient's compliance in using the Tinospora extract, especially for the pediatric patients. Encapsulation was a coated process of drug using solid or liquid form of thin layer. The encapsulation process was used at the pharmaceutical and food industry to mask the bitter taste of product and protect the active ingredients from oxidation process. The study aims were to encapsulate the Tinospora extract with sodium alginate by drips method.

Methods: Brown algae (Sargassum ilicifolium) were a resource of alginate acid. Brown algae were macerate using HCl $5 \%$ to produced alginate acid, and sodium alginate was obtained by adding $\mathrm{Na}_{2} \mathrm{CO}_{3} 5 \%$ to alginate acid solution. The study revealed that sodium alginate resulted from brown algae isolation process was $19.98 \%$ of the wet weight of brown algae. The formula of Tinospora extract microencapsulation was design into three formulas with different sodium alginate concentrations ( $\mathrm{F} 1=0.5 \%, \mathrm{~F} 2=1 \%$, and $\mathrm{F} 3=1.5 \%)$.

Results: The microcapsule resulted from three formulas had the various weight of xerogel alginate but with similar diameter. Xerogel alginate weight of F1 was $1.98 \mathrm{~g}$, F2 was $2.15 \mathrm{~g}$, and F3 was $3.21 \mathrm{~g}$. It can be concluded that the weight of xerogel alginate microcapsule and form of microcapsule were depended on the sodium alginate concentration.

Conclusions: The xerogel alginate microcapsule was evaluated for pre-formulation test, and the results showed that the microcapsule met the requirements of pre-formulations parameters without the adding of lubrication compound. The hedonic organoleptics test revealed that the microencapsulation process was able to cover the bitter taste and odor of Tinospora extract.

Keywords: Encapsulation, Xerogel alginate, Tinospora, Brown algae.

(C) 2017 The Authors. Published by Innovare Academic Sciences Pvt Ltd. This is an open access article under the CC BY license (http://creativecommons. org/licenses/by/4. 0/) DOI: http://dx.doi.org/10.22159/ajpcr.2017.v10i11.16517

\section{INTRODUCTION}

Brown algae (Sargassum ilicifolium) are one source of raw materialproducing alginate that widely used and available in Indonesia, especially North Sumatra [1]. Brown algae have xantofil pigment that gives the brown color and can produce algin or alginic. The concentration of alginate in brown algae was depended on the season, the growing, harvesting, and types of algae [2]. Sodium alginate is the final product of alginate extraction process. Sodium alginate is widely used in the pharmaceutical field as a suspending agent, thickening agent, stabilizer oil in water emulsion, and as a binder and a disintegrator of a tablet formulation [3].

Brotowali (Tinospora crispa) is well known as a bitter medicinal plant and traditionally has been used to treat rheumatism, gout, bruise, and fever and also to stimulate appetite [4]. The bitter flavor of Tinospora extract has decreased the patient's compliance in using the Tinospora extract, especially for the pediatric patients. Sodium alginate is water soluble and thickens to form a stable solution and have a possibility to use it in the encapsulation process of Tinospora extracts, thus protecting the active ingredients of the condition of decay or the evaporation of the active component. Furthermore, since the active ingredient protected by a matrix system (encapsulated materials), this condition was able to prevent the decline in food or drug quality such as discoloration, an unwanted condition of the product [5]. The encapsulation process also prevents the deactivation of drug during the delivery process due to the protection by the polymer shell, and this ensures sufficient amount of drug reaching the intended area [6].
Based on this, the researchers were interested in isolating the sodium alginates from brown algae (S. ilicifolium) and use it to encapsulate the extracts of Tinospora using drips method with the aim to covering the taste and smell of Tinospora which is very bitter so that it can improve patient compliance in taking the herbal drug $[7,8]$.

\section{MATERIALS AND METHODS}

Materials

The materials used in this study include sodium alginates isolated from brown algae (S. ilicifolium) and Tinospora extract (T. crispa (L.) miers). The chemicals used are hydrochloric acid, sodium carbonate, hydrogen peroxide, sodium hypochlorite, calcium chloride and $\mathrm{CO}_{2}-$ free distilled water, ethanol $70 \%$. The tools used in this research are the glass tools laboratory (pyrex), blender (national), a modified water bath, oven (memmert), furnace (thermolyne), viscometer (Myr), balance (Vibra ht), desiccators, pH meter, flannel strainer, and rotary evaporator (Shimadzu).

\section{Methods}

\section{Preparation of Tinospora extract}

About $600 \mathrm{~g}$ of Tinospora powder was macerated with $4.500 \mathrm{~mL}$ ethanol $70 \%$ in the closed chamber for 5 days and covered from the sun light and stirred once a day. The solution resulted from the maceration was strained with flannel strainer (Solution I), and the waste substances were macerated again with $1.500 \mathrm{~mL}$ ethanol $70 \%$ for 2 days. The second maceration process was done with similar methods 
with the first process until the second maceration result (Solution II) was obtained. The Solutions I and II were mixed and evaporated with rotary evaporator apparatus until the viscous Tinospora extract was obtained [9].

\section{Encapsulation process}

Microencapsulation is a dosage form technology that can release their contents at controlled rates under specific conditions [10]. Microcapsules of Tinospora extract formulated using variation of sodium alginate concentrations. Sodium alginate used in this study was obtained from the isolation of a brown alga (S. ilicifolium) taken from the coast of Sibolga, North Tapanuli. The formula of microcapsules of Tinospora extract was shown in Table 1.

Sodium alginate weighed as much as $0.5 \mathrm{~g}, 1 \mathrm{~g}$, and $1.5 \mathrm{~g}$ then put in a $100 \mathrm{ml}$ glass beaker, add $40 \mathrm{ml}$ of distilled water then stirred until expand completely. The Tinospora extract dispersed into a solution of sodium alginate then stirred until homogeneous. The distilled water then added until the limit mark. Once homogeneous, the suspension of extract Tinospora in sodium alginate was pipette using a small pipette and dropped into a solution of $0.15 \mathrm{M} \mathrm{CaCl}_{2}$ to form a gel. The formed gel was allowed for 15 minutes in the solution of $0.15 \mathrm{M} \mathrm{CaCl}_{2}$ then filtered, and the gel dried in an oven at a temperature of $50^{\circ} \mathrm{C}$ for $2 \mathrm{hrs}$ until dry. After dried, the alginate gel in the form of microcapsules was evaluated [11].

\section{Granules characterization}

\section{Angle of repose}

The determination of the angle of repose was done using a funnel flow that has been assembled. The granules were added into the funnel, the surface was flattened, then opened the bottom cover of funnel, and the granules allowed to flow through the funnel $[12,13]$. The angle of repose can be determined by the following formula:

Tangent $\theta=2 \mathrm{~h} / \mathrm{D}$.

Where,

$\theta=$ Angle of repose,

Table 1: The formula of microcapsules of Tinospora extract

\begin{tabular}{llll}
\hline Composition & \multicolumn{2}{l}{ Formula } & \\
\cline { 2 - 4 } & F1 (0.5\%) & F2 (1\%) & F3 (1.5\%) \\
\hline Sodium alginate $(\mathrm{g})$ & 0.5 & 1 & 1.5 \\
Tinospora extract $(\mathrm{g})$ & 5 & 5 & 5 \\
Aquadestilata $(\mathrm{ml})_{\mathrm{CaCl}_{2} 0.15 \mathrm{M}(\mathrm{ml})}$ & 100 & 100 & 100 \\
\hline
\end{tabular}

Table 2: The result of encapsulation process with various sodium alginate concentrations

\begin{tabular}{llllll}
\hline \multirow{2}{*}{$\begin{array}{l}\text { Formula } \\
(\mathbf{n}=6)\end{array}$} & \multicolumn{2}{l}{ Weight $(\mathrm{g})$, mean \pm SD } & & \multicolumn{2}{l}{ Diameter $(\mathbf{m m})$} \\
\cline { 2 - 3 } \cline { 6 - 7 } & Wet & Dry & & Wet & Dry \\
\hline F1 $(0.5 \%)$ & $54.41 \pm 0.37$ & $1.98 \pm 0.14$ & & 3.86 & 1.11 \\
F2 $(1 \%)$ & $60.84 \pm 0.54$ & $2.11 \pm 0.1$ & & 3.86 & 1.11 \\
F3 $(1.5 \%)$ & $82.66 \pm 0.55$ & $3.25 \pm 0.1$ & & 3.86 & 1.11 \\
\hline
\end{tabular}

SD: Standard deviation $\mathrm{h}=$ The high of cone $(\mathrm{cm})$

$\mathrm{D}=$ Diameter $(\mathrm{cm})$,

Requirement: $20^{\circ}<\infty<40^{\circ}$.

Flowing time

The determination of flowing time was done using a funnel flow. The granules were added into a funnel that has been assembled then the granule surface leveled. Then, the bottom cover of funnel was opened, and stopwatch turned on simultaneously. The stopwatch stopped when all the granules have gone past the funnel and the flowing time required by granules recorded $[12,13]$

The requirements: $\mathrm{t}_{\text {flow }}<10$ detik.

Compressibility index

About $50 \mathrm{~mL}\left(\mathrm{~V}_{1}\right)$ of granules were added into the compressibility index apparatus, then press the "on" button at the apparatus. The apparatus was operated until the constant volume obtained $\left(\mathrm{V}_{2}\right)[12,13]$

$$
\text { Compressibility index }(\mathrm{I})=\frac{\mathrm{V}_{1}-\mathrm{V}_{2}}{\mathrm{~V}_{1}} \times 100 \%
$$

Requirements: $\mathrm{I} \leq 20 \%$.

Organoleptic test of xerogel

The organoleptic test of xerogel flavor was done using hedonic test of 10 panelis. The numerical scale was used in the flavor determination test [14].

\section{RESULTS AND DISCUSSION}

\section{Tinospora extract encapsulation}

The Tinospora extract encapsulation process by sodium alginate was done by drips method. The result of encapsulation process was shown in Table 2.

Sodium alginate can be used as a thickener, suspending agent, stabilizer, and gel, so when a suspension of Tinospora extract in sodium alginate was added into a solution of calcium chloride, there will be an exchange between the calcium ions with sodium ions and form a gel.

The gel produced in this study was a type of water-containing gel (hydrogel) and lost liquid gel (xerogel). The extract Tinospora suspension in sodium alginate dripped into a solution of calcium chloride that will be formed hydrogel directly. In the encapsulation procedure, the hydrogel was taken, after allowed it for 15 minutes in the calcium chloride solution, so that all the sodium alginate reacts with calcium ions, and after hydrogel dry, it will form a smaller form of xerogel [15].

Encapsulation process by drips method was also known with extrusion method. The gel was formed after the sodium alginate suspension dripped into the $\mathrm{CaCl}_{2}$. It was because the cross binding of carboxylate anion $\left(\mathrm{COO}^{-}\right)$from alginate monomer and divalent cation $\left(\mathrm{Ca}^{+}\right)[16]$.

Effect of sodium alginate concentration on the diameter and weight of the microcapsules

The influence of the concentration of sodium alginate to the diameter and weight of the microcapsules resulted from the encapsulation process was shown in Table 2. The result indicated that the diameter of

Table 3: Microcapsules characterization results

\begin{tabular}{lllllll}
\hline Formula (n=6) & $\begin{array}{l}\text { Flowing } \\
\text { time (seconds) }\end{array}$ & Statistical test & $\begin{array}{l}\text { Angle of } \\
\text { repose }\left(\mathbf{2 0}^{\circ}<\mathbf{\infty}<\mathbf{4 0} \mathbf{0}^{\circ}\right)\end{array}$ & Statistical test & $\begin{array}{l}\text { Compressibility } \\
\text { index }(\mathbf{I} \leq \mathbf{2 0} \mathbf{0})\end{array}$ & Statistical test \\
\hline F1 & $6.01 \pm 0.13$ & $\mathrm{p}<0.05$ & $26.51 \pm 0.36^{\circ}$ & $\mathrm{p}<0.05$ & $8.41 \pm 1.08$ & $\mathrm{p}<0.05$ \\
F2 & $7.06 \pm 0.15$ & & $24.35 \pm 0.47^{\circ}$ & & $8.41 \pm 0.61$ & \\
F3 & $9.03 \pm 0.21$ & $24.47 \pm 0.51^{\circ}$ & & $6.08 \pm 0.94$ & \\
\hline
\end{tabular}


microcapsules from all of the formulas has a similar diameter: $3.86 \mathrm{~mm}$ wet and dry diameter $1.11 \mathrm{~mm}$. This is because the hydrogels were taken from the calcium chloride solution at the same time, after settled for 15 minutes in a solution of calcium chloride [11]

The microcapsules of encapsulation process have a difference of dry and wet weight. The best result was obtained in F3 (1.5\%) with $82.66 \pm 0.55 \mathrm{~g}$ wet weight and dry weight of $3.25 \pm 0.1 \mathrm{~g}$. The microcapsules was dried in an oven at temperature of $50^{\circ} \mathrm{C}$ for $2 \mathrm{hrs}$. The complete result can be seen in Table 2 . The data in Table 2 revealed that the higher concentration of sodium alginate was used, it will produce a higher dry weight of microcapsules and a better form of microcapsules obtained as a polymer coating that coats Tinospora extract was bigger. These results were expected to provide adequate protection to the encapsulated Tinospora extract.

Encapsulation process of Tinospora extract according to the method used in this research revealed that if we used sodium alginate concentrations over than $1.5 \%$, it will be difficult to do because the mixture becomes very thick and make it difficult to drips into the $\mathrm{CaCl}_{2}$ solution.

\section{Microcapsules characterization}

Microcapsules characterization was done by flowing time, angle of repose, and compressibility index parameters. The result was shown in Table 3.

Table 3 shows the differences of microcapsules characterization from the three formulas. The flowing time of the microcapsules of F1 $(0.5 \%)$ was $6.01 \pm 0.13$ seconds, F2 $(1 \%)$ was $7.06 \pm 0.15$ seconds, and F3 (1.5\%) was $9.03 \pm 0.21$ seconds. It can be concluded that the addition of sodium alginate concentration will increase the flowing time of microcapsules. The angle of repose microcapsules of F2 was $24.35 \pm 0.47^{\circ} \mathrm{F} 3$ was $24.47 \pm 0.51^{\circ}$, and $\mathrm{F} 1$ has $26.51 \pm 0.36^{\circ}$ of angle of repose. The compressibility index of $\mathrm{F} 1$ and $\mathrm{F} 2$ was $8.41 \pm 1.08 \%$ and $8.41 \pm 0.61 \%$, respectively, and the F3 has $6.08 \pm 0.94 \%$ of compressibility index [13]. The statistical test using one-way ANOVA methods revealed significant differences $(\mathrm{p}<0.05)$ on flowing time, angle of repose, and compressibility index between all formulas. The results of the characterization of the microcapsules can be seen that the three formulas met the requirements for flowing time, angle of repose, and compressibility index, and it can be concluded that the microcapsules can be used in capsule formulation.

\section{Organoleptics test}

The test results of the 10 panelists revealed that the encapsulated process was able to mask the bitterness flavor of the Tinospora extract. The higher of the concentration of sodium alginate used, the taste becomes less bitter.

\section{CONCLUSION}

Based on the analysis of the study result, it can be concluded that the Tinospora extract can be encapsulated with sodium alginate isolated from brown algae using drips method and the microcapsules characterization of encapsulated Tinospora extract of the three formulas met the requirements of the microcapsules.

\section{REFERENCES}

1. Rimelda N. Isolation and characterization of Na-alginate from brown algae (Sargassum plagyophyllum (Mertens) J.G. Agardh and the Effect of the Bleaching Composition Concentration on Viscosity. A Thesis. Medan: Universitas Sumatera Utara; 2013.

2. Agoes A. Indonesia's Herbal Medicine. Jakarta Selatan: Salemba Medika; 2010. p. 15.

3. Basmal J, Yunizal J, Murtini T, Nasran S, Marsiana E, Abdulrokim I, et al. The Production of Alginate From Sargassum Seaweed. Jakarta Timur: Penebar Swadaya; 2013. p. 5, 9, 27.

4. Dalimartha S. The Prescription of Herbal Medicine for Uric Acid. Jakarta: Penebar Swadaya; 2008. p. 41-2.

5. Wilson N, Shah NP. Microencapsulation of vitamins. ASEAN Food J 2007;14(1):1-14.

6. Biswal I, Dinda A, Das D, Si S, Chowdary KA. Encapsulation protocol for highly hydrophilic drug using non-biodegradable polymer. Int J Pharm Pharm Sci 2011;3(2):256-9.

7. Yuliana S. Mikroencapsulation: Strategic Approach in food Fortification. Bogor: Balai Besar Penelitian dan Pengembangan Pascapanen Pertanian; 2011.

8. Yunizal. Extraction Technology of Alginate. Jakarta: Pusat Riset Pengolahan Produk dan Sosial Ekonomi Kelautan Dan Perikanan; 2004.

9. Budi K, Team L. Brotowali: Effication and Application. Jakarta: Agromedia Pustaka; 2003. p. 25-9.

10. Preeti K, Jathi K. Chitosan-sodium alginate biodegradable interpenetrating polymer network (IPN) beads for delivery of loxacin hydrochloride. Int J Pharm Pharm Sci 2010;2 Suppl 2:77-82.

11. Samran. Encapsulation and Released of Chloramphenicol From Gel of Alginat. A Thesis. Medan: Universitas Sumatera Utara Medan; 1992. p. 2-3.

12. Ansel HC. Pharmaceutical Dosage Form. Jakarta: UI Press; 2008.

13. Lachman L, Lieberman HA, Kanig J1. Theory and Practice of Pharmaceutical Industry II. $3^{\text {rd }}$ ed. Jakarta: Universitas Indonesia; 2008. p. 649-60, 886.

14. Soekarto SP, Soewarno T. Organoleptics Evaluation for Food and Farm Industry. Bogor: Pusbangtepa IPB-Press; 1981.

15. Yuan Z, Fei Y, Hong C, Jie Z, Jie M, Junhong C. Alginate/graphene double-network nanocomposite hydrogel beads with low-swelling, enhanced mechanical properties, and enhanced adsorption capacity. J Mater Chem A 2016;4:10885-92.

16. Mawaddana Q. Viability study of microencapsulation of Lactobacillus casei by Na-alginate matrix. Faculty of Medicine and Health. Pharmaceutical Department. Jakarta: UIN Syarif Hidayatullah; 2015. 